\title{
Mads Michelsens sølvsamling
}

Bidrag til en karakteristik af Åbenrås guldsmedekunst

Af Sig. Schoubye

Afdøde amtslæge Mads Michelsen havde i sit pompose hjem i Åbenrå blandt mange andre herligheder en samling af sølvgenstande, fortrinsvis udført af Åbenrå-guldsmede, som det var ham en særlig glæde at fremvise for de gæster, hvem en rundgang i hjemmet under hans inciterende vejledning var forundt. Man mærkede snart, at sølvet havde hans, den ellers så alsidige samlers, særlige kærlighed, og $i$ en lille bog beskrev han lige til det sidste leveår omhyggeligt og med sirlig skrift hver af samlingens genstande og anførte, af hvilke mestre de var udført.

Langt den overvejende del af det antike sølv var fra Åbenrå. På et vist tidspunkt har han næret planer om at skildre Ảbenrå-guldsmedenes arbejder, og samlingens righoldighed og sjældenhed gav ham alene mulighed for det. Det lykkedes ham desværre ikke. Stoffets mangfoldighed tog vel magten fra ham som fra mange andre, som har været grebet af kunsthåndværkets udefinerbare charme og de anonyme mestre bag det. Han nåde imidlertid at efterlade sig et materiale, som det $\mathrm{i}$ dag ville være umuligt at tilvejebringe, og som vil være en uundværlig kerne i den skildring af det åbenråske guldsmedehåndværks udvikling, som før eller siden må komme.

Takket være interesse og forståelse hos hans to sønner er det muligt at give en præsentation af samlingens væsentligste genstande og samtidig dermed at skitsere en sønderjysk købstads guldmedekunst gennem 200 år.

Hvad de personalhistoriske og stempelmæssige oplysninger angår, skyldes de alene, hvad afdøde lektor Chr. A. Bøje i samarbej- 
de med Michelsen samlede til sit store opslagsværk Danske Guldog Sølvsmedemærker før $1870^{2}$. Der er ingen tvivl om, at adskilligt mere materiale vil kunne graves frem, ligesom visse revisioner af stemplerne vil være nødvendige, når det endelige arbejde om Åbenrå-guldsmedene skal udarbejdes. Til brug for sammenligninger med landets $\emptyset$ vrige guldsmedearbejder henvises $i$ forbindelse med illustrationerne til Boesen og Bøjes standardværk og til Bøjes lille bog om hovedvandsæg‘, men ellers er vi fattige på litteratur om dette emne. Den eneste gang emnet har været strejfet i Sønderjyske Årbøger er i en artikel fra 1940 om nogle sønderjyske sølvarbejder fra Augustenborg Slot af Jørgen Paulsen, som der ligeledes vil blive henvist til ${ }^{5}$.

Ifølge Bøje har Åbenrå siden 1600 haft 36 guldsmede, hvoraf de 27 har kunnet identificeres på grundlag af stempler. Af disse 27 mestre var det lykkedes Michelsen at samle genstande fra de 22, et anseligt resultat.

Ved hans død bestod samlingen af 185 numre Åbenrå-sølv, omfattende

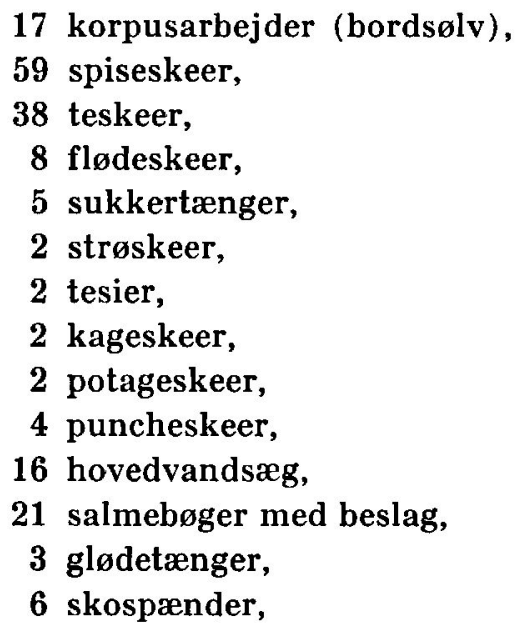

alle stemplede arbejder.

Den ældste repræsenterede guldsmed i samlingen er Anders v. Barm, tilhørende et kendt guldsmededynasti i landsdelen (Tønder, Haderslev, Sønderborg, Kiel), måske stammende fra Bergen. Oblatæsken i Nicolai kirke i Åbenrå, og et kongeskjold fra 1734 i 
Åbenrå skyttelaug er udført af ham. I samlingen her er der ikke mindre end 10 arbejder, 1 sukkerstrøbasse, 5 spiseskeer og 4 teskeer.

Sukkerstrøbøssen fig. 2 er af gængs form, men et fornemt arbejde, som dokumenterer, at Åbenrås guldsmede allerede $\mathbf{i}$ tiden efter 1700 beherskede det internationalt gældende formsprog inden for håndværket. Kronen over monogrammet opfattede Michelsen som en hertugkrone.

Af spiseskeerne er de tre gengivet som fig. 14-16. Den første er den ældst daterede ske fra Ảbenrå, 1712, det år, v. Barm formodes at have etableret sig. Både denne ske og fig. 16 er en almindeligt forekommende baroktype med fliget skaft. Den lille akantusgravure på overgangen til skebladet - laffen - som ses på fig. 14, er et træk, som var yndet af Tønder-guldsmedene på samme tid, det første af mange senere, som viser intim forbindelse blandt guldsmedene i disse to byer.

Derimod er sketypen fig. 15 en ejendommelig åbenråsk særform, hvor man med stædig konservatisme bevarer renæssancens 8-kantede hulskaft i stilken sammen med en moderne baroklaf. Formen må være blevet populær i byen, da også senere mestre overtog den, jvf. fig. 19 og 20.

Den næste er Carl Christian Hoffmeister, v. Barms yngre samtidige, kendt som oldermand for skyttelauget $1743 \mathrm{og}$ som mester til et par eksklusive baroklysestager fra Augustenborg. Af ham var der i samlingen oprindelig kun et traditionelt regencebæger fig. 7 , men siden suppleret med spiseskeen fig. 17 , der svarer til fig. 14.

Af Ludolph Thiesen, forfærdigeren af Nicolai kirkes kalk i Åbenrå 1751, forefindes en spiseske med hulskaft fig. 18, langt mere kunstfærdigt udført, end v. Barms tilsvarende. Rottehalen, som så hyppigt træffes på skeer fra kongeriget, er ikke almindelig i de nordslesvigske købstæder. Her nøjes man med som i dette tilfælde og på fig. 19 at markere den i gravure og omgive den med bladranker, i dette tilfælde af akantus. En lille glødetang fig. 29 med snoede ben og muslingformede gribere, er af en tiltalende stofmæssig fasthed, som i den karakterfulde overgang mellem stilk og laf i spiseskeen viser håndværksmæssig sikkerhed. 
Den Åbenrå-mester, der efter overleveringen at dømme har været mest produktiv, er Berthold Sørensen Rosendahl, som sammen med den florissante tids anden betydelige mester, den nedenfor omtalte F. C. Hansen, betegner højdepunktet i, hvad vi kender til Ảbenrås guldsmedekunst. I Michelsens samling er han da også den talmæssigt hyppigst repræsenterede, med ikke mindre end 28 arbejder.

Sukkerstrøbøssen, fig. 1, der er usigneret, og som man umiddelbart efter dens stilistiske kriterier ville placere i Alborg, er af Michelsen tillagt Rosendahl. Hvis dette er rigtigt (samtidige inskriptioner til statte for teorien foreligger desværre ikke), bekræftes atter en iøjnefaldende nord-sydgående bevægelse i sønderjysk sølvs form og stil, et forhold som selv er mærkbart i det så tyskprægede Tonder. Mere provinsielle er imidlertid de to andre gengivne sukkerbøsser, fig. 3 og 5 , der begge er signerede. De mangler unægtelig begge fig. 1's elegance. Sikrest udført er fig. 5 med den faste fodring. Af de mange overleverede spiseskeer - væsentlig i rokoko - er her medtaget en af de karakteristiske Åbenrå-skeer med 8-kantet hulskaft, hvoraf der er 5 i samlingen. Den slutter sig nær til Thiesens fig. 18.

Ikke mindre end 6 sølvbeslagne salmebøger med spænder og beslag af Rosendahl vidner om, at denne type har været populær. Perioden Rosendahl virkede i, 1753-99, er den egentlige blomstringstid for de beslagne salmebøger, der fra midten af århundredet bliver almindelig som bryllupsgave og en del af kvindernes personlige udstyr. Den ældst daterede er en salmebog med Thiesens mestermærke $i$ regencestil, dateret 1760 , foruden den ny salmebog fra 1757 indeholdende Det ny Testamente fra 1755 . Den her gengivne af Rosendahl fig. $41 \mathrm{må} \mathrm{være} \mathrm{fra} \mathrm{tiden} 0.1770$. Dens ramme og hjørneforstærkninger $i$ regence afviger ikke fra landsdelens øvrige, men selve spændet derimod har fået en udformning, som tør betegnes som lokal åbenråsk. Under de støbte sideplader og selve lukket ligger forgyldte sølvplader til fremhævelse af bånd- og blomsterornamenterne. Spændet virker kompakt og tungt og gedigent, som skulle det borge for ejerindens egen velstand og soliditet. De lette filigranarbejder fra vesteregnen er øjensynlig ikke faldet $i$ åbenråernes smag, eftersom den største 
del af kendte Åbenrå-salmebogsspænder er udført over denne af Rosendahl skabte læst.

Det største korpusarbejde af en Åbenrå-guldsmed er en aflang glat terrin på fire støbte ben, oprindelig udført til hertugen af Augustenborg. Den befinder sig nu på Frederiksborg? og vidner om, at mesteren, Fridrich Christopher Hansen, må have nydt tillid og have været anset for kapabel til at løse særlig krævende opgaver.

Bestanden af hans arbejder i Michelsens samling (22 numre) understreger denne kendsgerning. - Samlingens pragtstykke, en gedigen svajknækket rokokoskål, formentlig fra 1778 , fig. 4 , stråler af håndværksmæssig sikkerhed, men går, som det viser sig $\mathrm{i}$ næsten alt ældre provinssølv, ikke uden for normerne. Først op mod år 1800 vover de sønderjyske guldsmede at skabe egne former, brydende de storre byers herskerstilling.

Nær beslægtet med denne skål er to mindre runde sukkerskåle, hvoraf den ene er gengivet som fig. 11. Bægeret fig. 8 er i sin udformning ligeså traditionelt og kunne være udført $i$ en hvilken som helst dansk provinsby. Men Hansen virkede lige til 1795, og i senere arbejder lægger han betydelig mere selvstændighed for dagen. Den lille ovale sukkerskål fig. $11^{8}$ er rigtig sønderjysk og svarende til traditionerne fra hjemstavnsbyen Tønder, hvor typen lanceres af den betydelige Tønder-guldsmed Andreas Nissen.

Men mest hjemlig og åbenråsk er han i de 3 spiseskeer fig. 22, 23, 24, hvor han har skabt en model, der, hvor nær den end ligger de umiddelbare forbilleder fra Tønder, skulle blive de mest karakteristiske af alle til nu kendte sølvgenstande fra åbenråske guldsmedeværksteder. Louis XVI-stilens guirlande anvendt på spiseskeer og lignende mindre bordsølv samt på hovedvandsæg opnåede en påfaldende popularitet i Sønderjylland. Den er grundelementet $i$ den enkle og sirlige ske, fig. 22. Men det nye og dristige $\mathbf{i}$ kompositionen ligger i stilkendens udformning til en oval medaljon, der danner modstykke til laffen. Man kan vel diskutere smagen. Så enkel som skeen fig. $22 \mathrm{er}$, går det vel. Mere tvivlsom virker den påsatte - også tønderske - perlestav og den støbte guirlande fig. 23, som ikke her afgrænser medaljonen, men af hensyn til perlestaven er hængt på længere nede. Det er begribe- 
ligvis en smagssag, om man vil goutere typen, der ligefrem drives ud i karikatur på den tredje af skeerne fig. 24 , hvor der oven i købet indsættes en Tønder-urne i medaljonen.

De smukkeste arbejder af F. C. Hansen i Michelsens samling er dog to småting, en yndefuldt udført glødetang fig. 30 og en sukkertang fig. 31, den første rokoko, den anden Louis XVI, begge skabt med „edel Einfalt" og uden kunstlethed.

En ske-form - meget udbredt i vestkystbyerne, men ellers ikke almindelig i Åbenrå - med vanlig spatelformet stilkende, men med stilkens nedre ende adskilt fra laffen ved et kvadret eller rudeformet mellemstykke forekommer i Michelsens samling, udf $\not$ rt af Rudolph Nielsen fig. 20, en samtidig af Rosendahl og F. C. Hansen. Skeen med det trefligede skaft fig. 21 er ligeledes af Nielsen og viser hvorlænge former - gået af mode i storbyerne - holder sig i provinsen. Det samme kan siges om den noble tedåse $i$ regence-stil fig. 4 som må regnes blandt samlingens bedste korpusarbejder. Sukkerbakken fig. 12 svarer fremdeles til de i T $\phi$ nder, L $\emptyset$ gumkloster, Højer og Skærbæk så stærkt udbredte typer og understreger atter den nære forbindelse mellem Abenrås og vesteregnens guldsmede.

Den stilfulde og prunkl $\varnothing$ se regence-tedåse fig. 6 er udført af Hinrich Breundle, der virkede fra 1776, og som indleder et guldsmededynasti i Åbenrå med tre generationer. Han arbejder fortrinsvis $i$ rokokoens stil. Michelsens samling rummer 3 spiseskeer og 3 teskeer af ham i denne stil, men et af samlingens bedste hovedvandsæg - i stilren Louis XVI, fig. 32 - har han muligvis også udført, selv om mestermærket $\mathrm{HB}$ er en variant til B $\emptyset$ jes. Det er det ældste hovedvandsæg i samlingen. Mærkeligt nok lykkedes det ikke Michelsen at finde frem til de æeldre former af Rosendahl og F. C. Hansen".

F $\varnothing$ rst henimod år 1800 skabes det karakteristiske s $\phi$ nderjyske hovedvandsæg, som så helt behersker billedet i dette lille forn $\emptyset j-$ elige kapitel $\mathbf{i}$ dansk guldsmedekunst - med K $\phi$ benhavn som centrum i f $\varnothing$ rste halvdel af perioden $(1750-1800)$, og S $\varnothing$ nderjylland (specielt T $\phi$ nder og vestkysten) $\mathrm{i}$ anden (til 1850).

Den fra folkekunsten overtagne anvendelse af glasflusser på æggene træffes allerede i rokokoen (f. ex. på et æg af C. F. Hansen 
i privateje), men almindelig $i$ moderat form bliver den f $\phi$ rst i Louis XVI-stilen, navnlig hos den i T $\varnothing$ nder uddannede Thomas Jensen sen., fig. 35, for så i senempiren at udvikles til ren maner — med Åbenrå og S $\emptyset$ nderborg i spidsen.

Thomas Jensen, der var lærling hos den berømte Tønder-guldsmed Paul Hansen I, er Louis XVI-stilens mest markante mester i Åbenrå, og han indf $\varnothing$ rer der den ejendommelige urneske, som ellers kun kendes fra Tønder (jvf. dog fig. 24).

Den sekskantede vaseform med gemme $i$ bunden til kirkemønten bliver grundskemaet for samtlige hovedvandsæg i landsdelen, også i Åbenrå. Variationerne er naturligvis mange, men efterspørgslen har været så stor, at guldsmedene måtte gå over til seriefremstilling. Dette ses således hos empiretidens betydeligste guldsmed i byen, Johan Heinrich Schou, af hvem der i samlingen er to næsten helt ens, helforgyldte vaseformede æg, fig. 33. Også han ligger i disse meget nær de t $\varnothing$ nderske forbilleder, men er mere åbenråsk i de af Rosendahl inspirerede salmebogsbeslag fig. 42 44, hvoraf dog både fig. 42 og 44 med deres monogrammedaljoner ligger nær tilsvarende Bödewadt-arbejder fra T $\varnothing$ nder. Derimod er spiseskeen fig. 25 på godt - og vel navnlig ondt - helt hans egen. Forbindelsen bagud - til F.C. Hansen - er ikke vanskelig at $\varnothing j n e$, jvf. fig. 22.

Et sjældent firkantet hovedvandsæg af ham i 90'ernes stil ${ }^{10}$ er bygget over en af Paul Hansen I i T $\varnothing$ nder skabt form.

Fø̆rst efter 1840 får Åbenrå-æggene deres eget fysiognomi ved mestre som Andreas Breundle fig. 36, den sene Christopher Waidl $\phi v$ M $\phi l l e r$ fig. 37 og navnlig ved den meget produktive Peter Johannsen Petersen, hvorefter moden går ind. Af den sidstnævnte er et af samlingens st $\varnothing$ rste æg fig. 40 med ikke færre end 102 glasflusser $^{11}$, i højde kun overgảet af et af Thomas Jensen jun. fig. 39. Det er $\mathbf{i}$ h $\phi \mathbf{j}$ grad diskutabelt om denne nyskabelse var nogen vinding for guldsmedeprofessionen. Dens levetid blev i hvert fald kort. Nægtes kan det jo ikke, at disse barokke udartninger af hovedvandsægget $i$ dag er de højest betalte som samlerobjekter fra hin tid. Mens Tønder-guldsmedene helt gik over til de æskeformede (bogformede) lugteæsker, overtog S $\emptyset$ nderborg-mestrene konkurrencen med Åbenrå og slog alle rekorder for hovedvandsæg 
i form af pokaler. Fra at være et sirligt dragtsmykke med funktion endte det som prydgenstand på en nipshylde. - A Abenrå-guldsmedene har æren af denne udvikling.

Samtlige mestre fra og med Thomas Jensen sen. er med i samlingen. Når bortses fra hovedvandsæggene, skabes lidet nyt. Det skulle da være de mange variationer af puncheskeen, som særlig Peter Johannsen Petersen er mester for, et stykke kulturhistorie, som fortæller lidt om dagliglivet i fyrrernes borgerlige Åbenrå.

Vi nærmer os de skæbnesvangre år, hvor klokken går i slag for håndværket. Smukt holdes gamle guldsmedetraditioner i live $\mathbf{i}$ hele landsdelen, hos dynastiet Rode i Abenrå, hos Bödewadt'erne i T $\varnothing$ nder, hos Ulrich Johannsen i Sønderborg, men o. 1900 er festen forbi.

Tilbage står så minderne om de gode gamle dage, et udtryk som virkelig har gyldighed for håndværkets vedkommende. Samlere som amtslæge Michelsen har gjort en god dagens gerning ved den kærlighed til godt håndværk, de i deres nidkære samlermani har lagt for dagen, her gennem et langt og frugtbart liv. Man må $\emptyset$ nske, at det samlede ikke traditionen tro igen skal spredes, men at det må lykkes for Åbenrå museum at erhverve samlingen som helhed, hvorved museet vil blive en attraktion af usædvanligt format rigere, både som dokumentation for flittigt og godt håndværk - og som minde om en god borger.

\section{NOTER}

1 Nekrolog i Sønderjyske Arbøger 1958, 293/94.

2 Af praktiske grunde refereres til stemplerne i den af Politikens forlag udgivne folkeudgave fra 1954, forkortet BøJE.

3 Gudmund Boesen og Chr. A. Bøje: Gammelt dansk Sølv til Bordbrug, 1948. Siden forkortet Bo.

4 Chr. A. Bøje: Balsambøsser og Hovedvandsæg. 1950. Forkortet BB.

5 Artiklen omtaler mestre fra גbenrå og Sønderborg.

6 Gengivet 1 Paulsens forannæunte artikel i Sønderjyske Arbøger 1940.

7 Fig. 336 i Bo, og fig. A 1 i Paulsens afh. i Sønderjyske Arbøger 1940.

8 Tilsvarende skål gengivet 1 Bo., fig. 302 .

9 F. ex. fig. 42 i BB, rokokozg af Rosendahl, og fig. 67, tilsvarende af F. C. Hansen, begge i privat eje. Også af Rudolph Nielsen kendes hovedvandsæg. Smst. fig. 84, Louis XVI.

$10 \mathrm{BB}$, fig. 107, 1 privateje.

11 Pendant hos BB, fig. 123. 


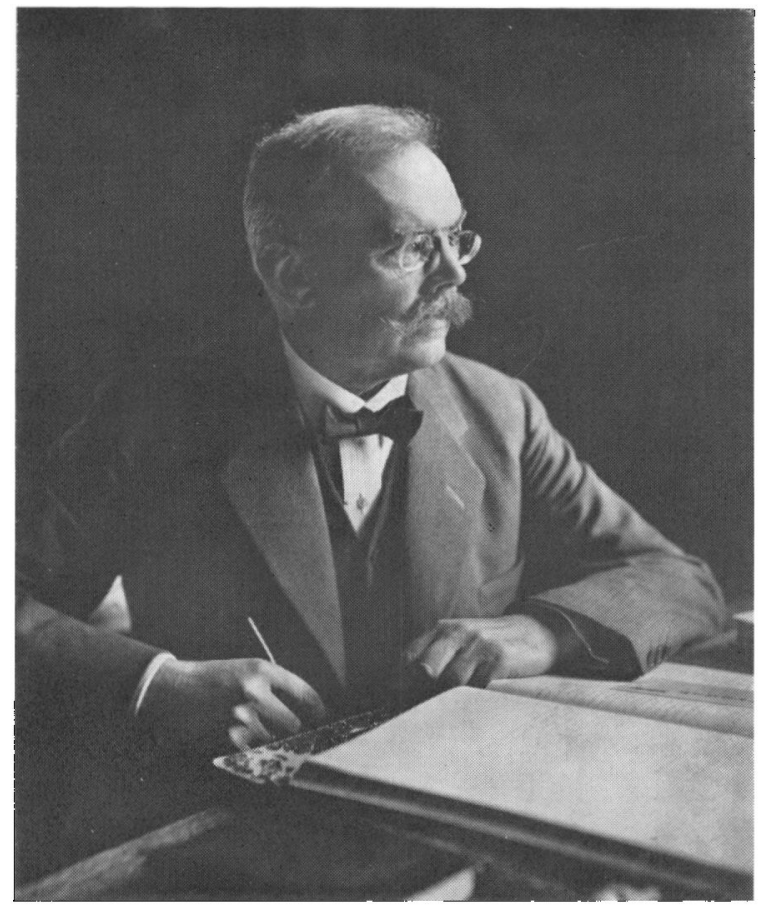

Mads Michelsen

$1873-1958$ 
Fig. 1. Sukkerstrobosse. Rokoko. Buget og svajknækket. 3 stobte ben. På låget stærkt stiliseret bladornamentik og en påsat stobt fugl (jvf. Bo., fig. 223). H. ca. $13 \mathrm{~cm}$. Sekundær inscription med årstal 1837. Uden stempler, men af Mads Michelsen tillagt Berthold Sorensen Rosendahl (1722-99), B. ( = Borgerskab) 23. 3. 1753.

Fig. 2. Sukkerstrabosse. Regence. Balusterformet og glat. Groft gennembrudt bladvark i låget (jvf. Bo. fig. 209 . H. ca. $15 \mathrm{~cm}$. Kronet monogram ALL. Åbenrå bymarke (Bøje 2. 1375). Mestermærke AVB (Bøje 2. 1385) = Anders v. Barm (1687-1750), B. o. 1712 .

Fig. 3. Sukkerstrobosse. Rokoko. Pareformet og svajknakket. 3 støbte ben. Gennembrurlt låg og stobt flad knop. H. ca. $11 \mathrm{~cm}$. Inscr.: Matz Nissen, Ellen Matzes in Schauby 1795. U. bym. Mestermarke BS (2 g.) (Bøje 2. 1390). Berthold Sørensen Rosendahl. 

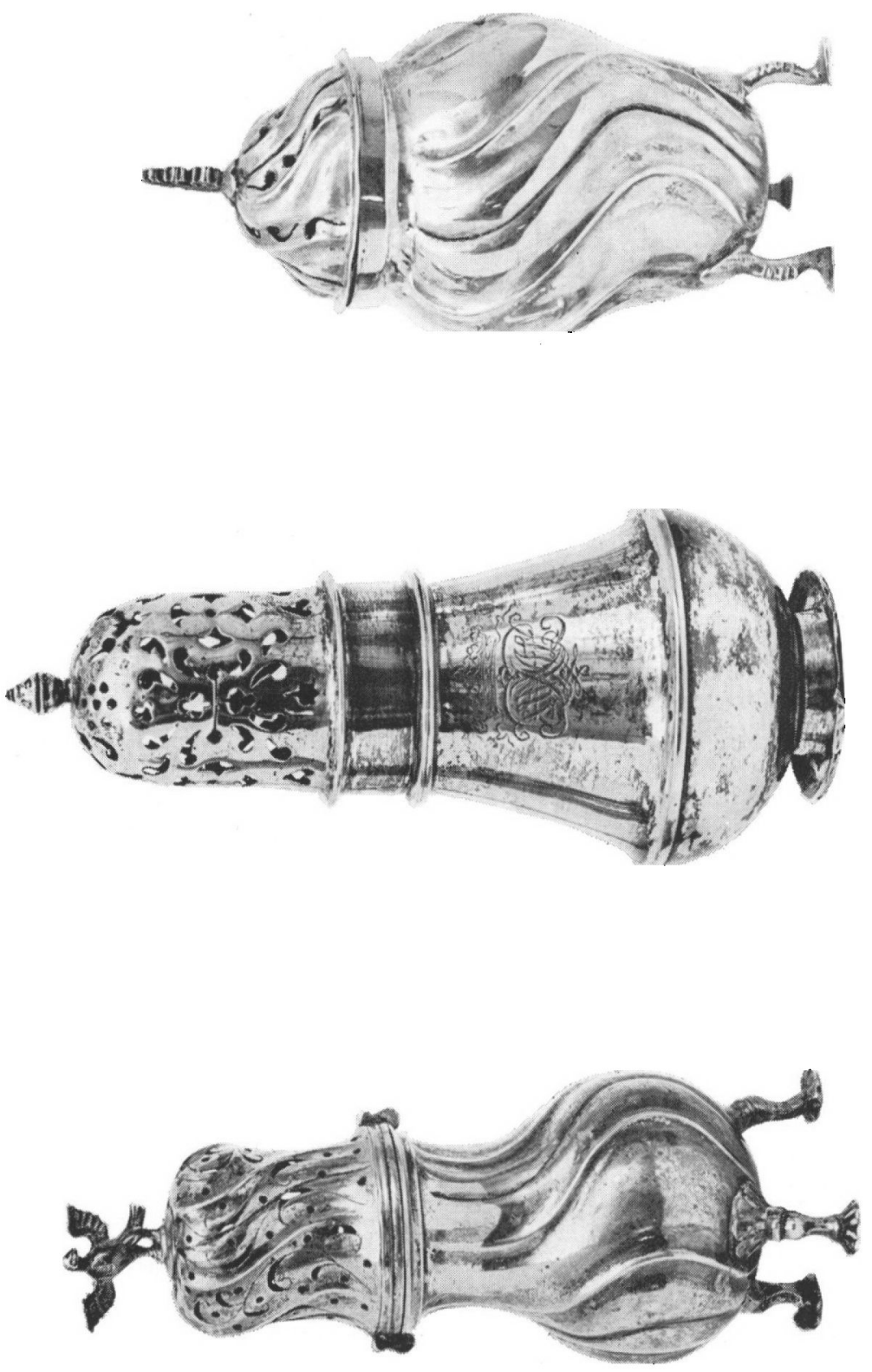
Fig. 4. Tedåse. Regence. Oval, lorlret ligeknakket, aftageligt hatteformet låg. H. 12,5 cm. Sekundær inscr. med årstal 1806, (jvf. Bo., fig. 182). Åbenrå bym. (Bøje 2. 1376). Mestermærke RN (Bøje 2. 1397). Rudolph Nielsen (1723-1810), B. o. 1749.

Fig. 5. Sukkerstrobssse. Rokoko. Pareformet, svajknæxket, med fast standkant (jvf. i ovrigt fig. 3). H. ca. $131 \frac{1}{2} \mathrm{~cm}$. Inscr.: A. M. Biörnsens Ao 1780 I. F. Biörnsen. Ābenrå bym. + Mestermærke BS - Rosendahl.

Fig 6. Tedase. Regence. Oval, to enkle lodrette ligeknæk, aftageligt hætteformet låg. $H .10 \mathrm{~cm}$. Sekundier inscr.: Barsmark 1833. Uden bym. Mestermærke HB (Bøje 2. 1399). Hinrich Breundle (1746 92). B. 10.5. 1776. 

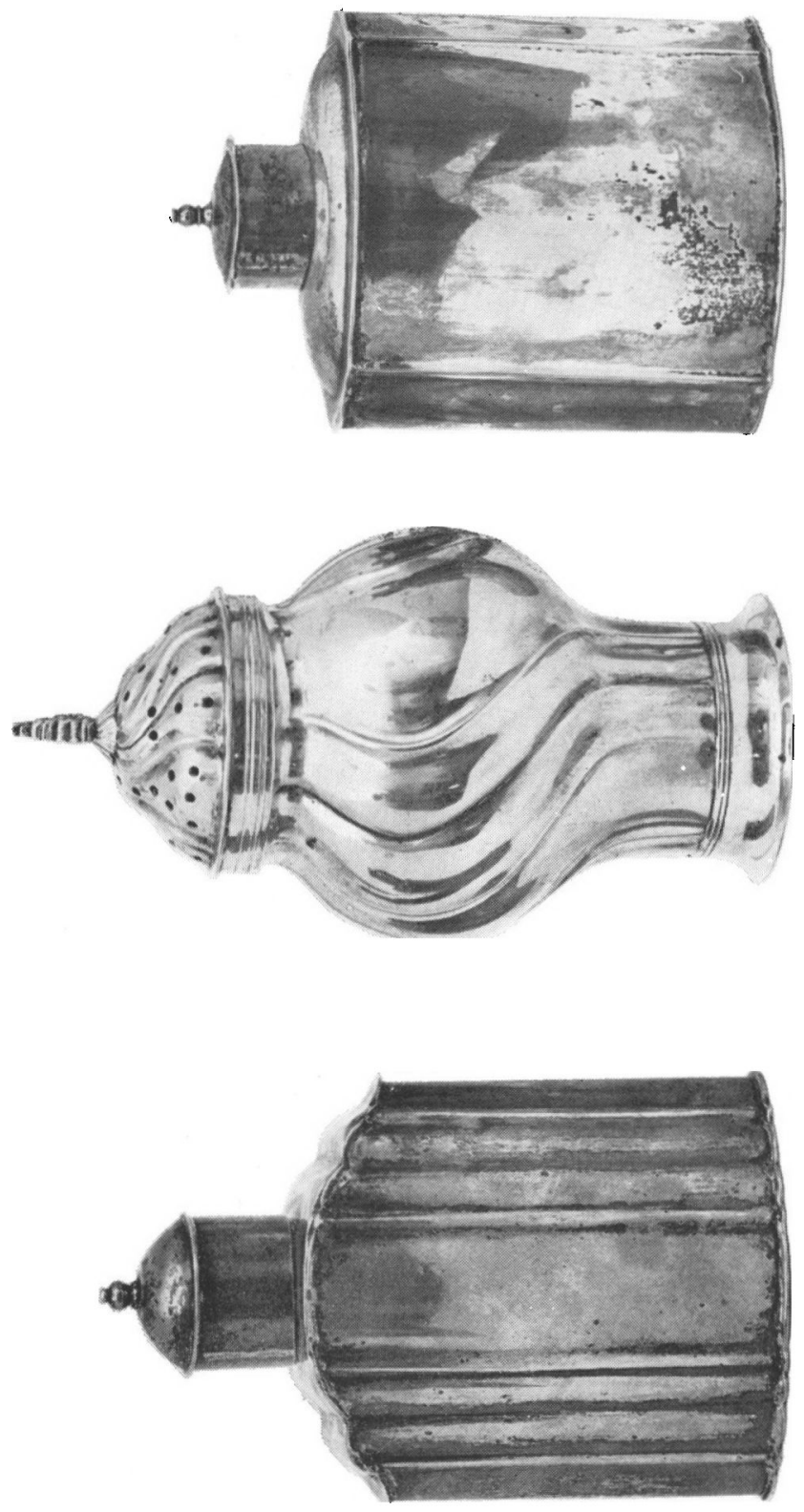
Fig. 7, Bæger. Regence. Bladgravure under drikkeranden. H. ca. $8 \mathrm{~cm}$. Sek. inscription 1846. Åbenrå bymærke (Bøje 2. 1376). Mestermærke CCH (Bøje 2. 1387). Carl Christian Hoffmeister.

Fig. 8. Bager. Regence. Blomstergravure på siden. Inscr.: Jens Hansen in Darhoff 1771. H. ca. $7 \mathrm{~cm}$. Ả benrå bym. og mestermæerke for Fridrich Christopher Hansen (1735-95), B. 4. 1. 1760. (Bøje 2. 1394).

Fig. 9. Spølkum (?). Rokoko. Oval, svajknækket. 3 støbte ben med muslinger. 16,5 $\times 11,5 \mathrm{~cm}$. Inscr.: Hans Heisel Senior. Johan Adam Regenburg. 1778. W. 181/2 L. Sekundære inscr. 1859 og 1903. Åbenrå bymærke (Bøje 2. 1377) og mestermærke FCH (Bøje 2. 1394). Fr. Chr. Hansen. 

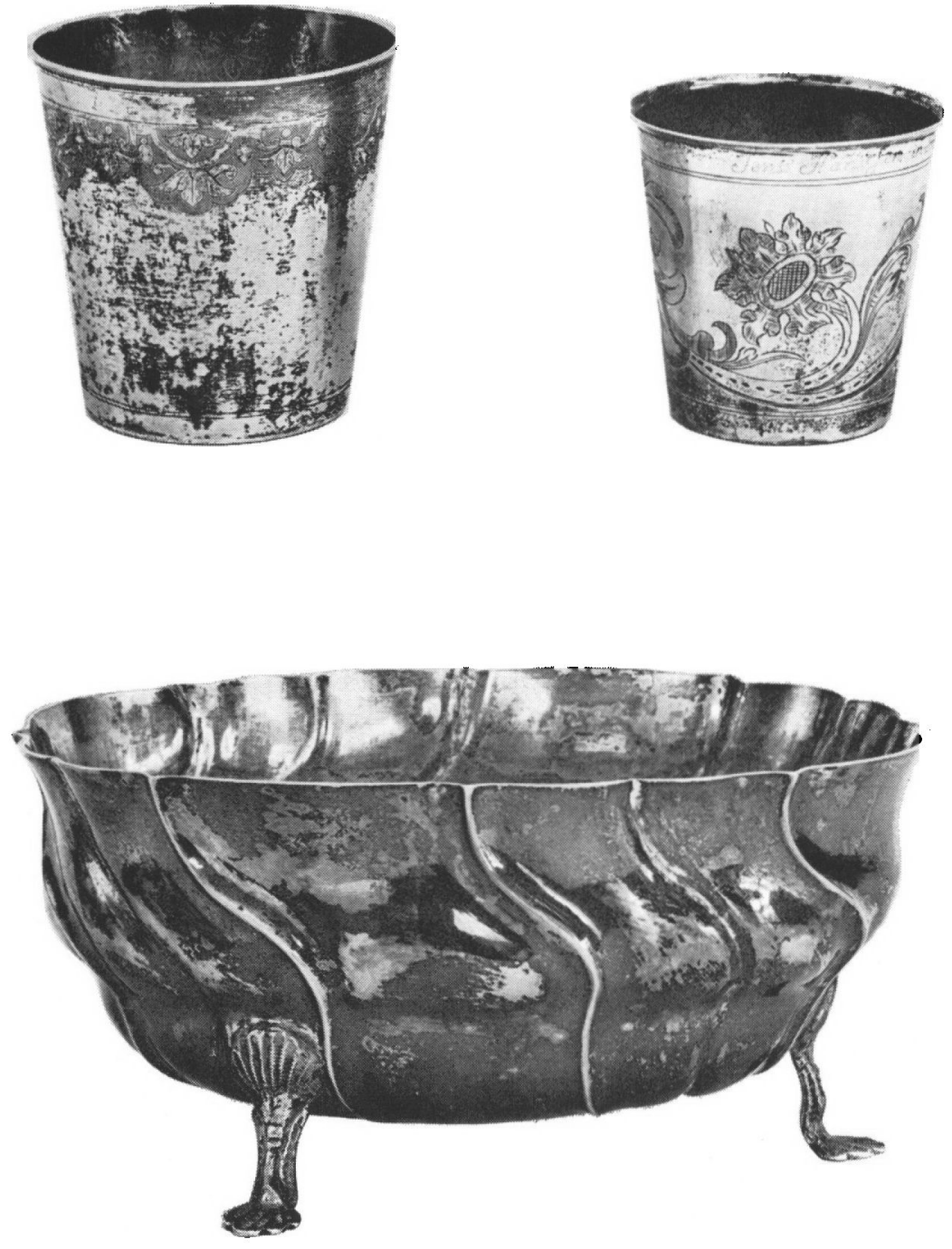
Fig. 10. Sukkerskål. Oval, på fod, med 8 lige knæk og udhamrede rocailler. $14,5 \times 11,5 \mathrm{~cm}$. Inscr.: Jacob Bruhn 1771. NHB. Åbenrå bymærke (variant til Bøje 2. 1376) og mestermærke FCH for Fr. Chr. Hansen (jvf. Bo., fig. 302).

Fig. 11. Sukkerskål. Rokoko. Svajknækket på 3 støbte gen. Diam. $11 \mathrm{~cm}$. Inscr.: Hans Kopperholdt in Barsmark 1798. Åbenrå bymærke (Bøje 2. 1377) og mestermærke for Fr. Chr. Hansen.

Fig. 12. Sukkerskål. Regence. Oval med ligeknæk i skål og på foden, stiliseret blomstergravure, hamring i foden. Støbt bolt med stjerneform. $14,5 \times 10,5 \mathrm{~cm}$. Inscr.: Throens Jürgens $1765 \mathrm{og}$ Jürgen Jessen in Aubeck. Åbenrå bym. (Bøje 2. 1377) og mestermærke RN for Rudolph Nielsen.

Fig. 13. Sukkerskål. Rokoko. Afrundet firkant på oval fod. 8 lige knæk og udhamrede rocailler. $16 \times 10,5 \mathrm{~cm}$. Inscr.: MMS in Blaasholm 1799 . U. bym. Mestermærke TI (Bøje 2. 1402) for Thomas Jensen sen. (1764 -1825), B. 29. 4. 1796. 

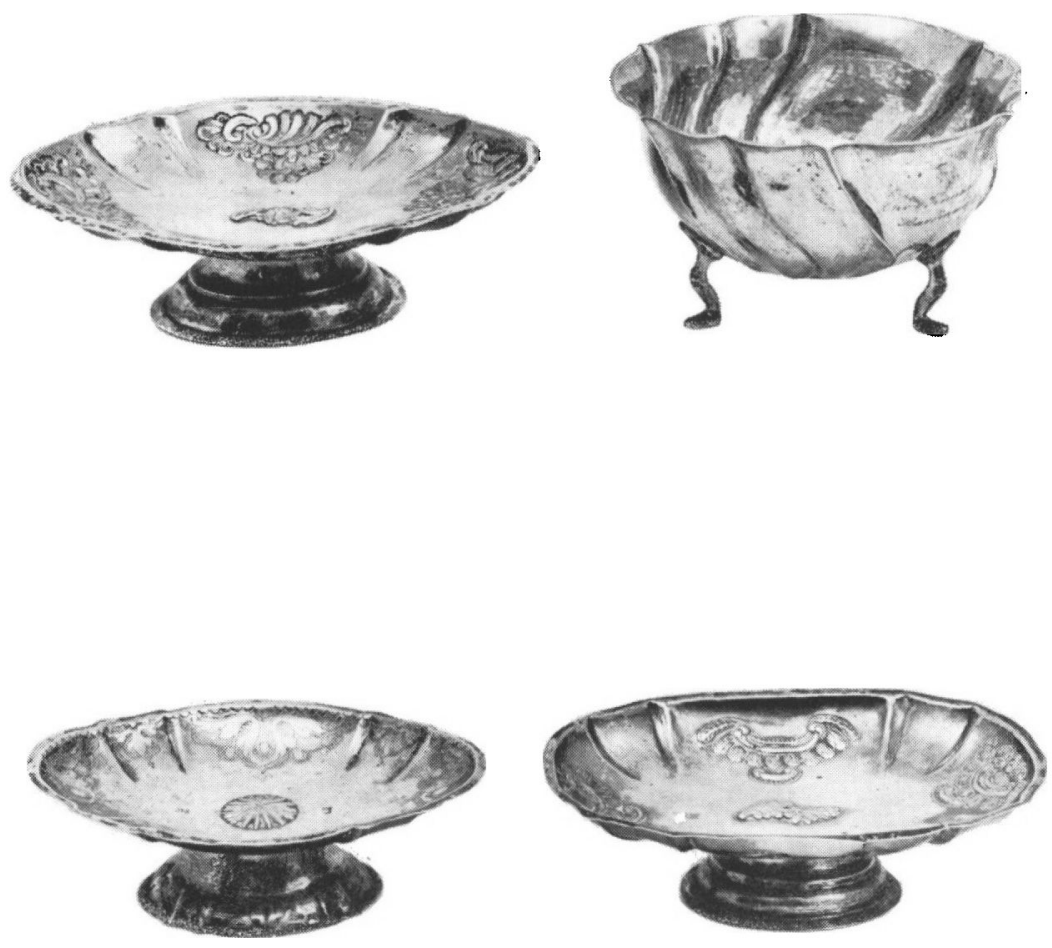
Fig. 14. Spiseske. Barok. Fliget skaft og blomstergravure. I. $0.20 \mathrm{~cm}$. Inscr.: Asmos Knudtsen 1712. Åbenrå bymarke (Bøje 2.1372). Mestermærke AVB (Bøje 2.1385). Anders v. Barm.

Fig. 15. Spiseske. Barok. 8-kantet hulskaft. Inscr. Hans Lausen 1746. Åbenră bymarke (Bøje 2.1376). Samme mestermærke som foran.

Fig. 16. Spiseske. Barok. Fliget skaft og blomstergravurer. Inser.: Gonder Jesses in Hastrup 1758. Åbenrå bymærke (Bøje 2. 1374). Samme mestermærke som foran.

Fig. 17. Spiseske. Barok. Fliget skaft og blomstergravure. Ābenrå bymarke of mestermarke CCH (Bøje 2.1387) for Carl Christian Hof-meister. 

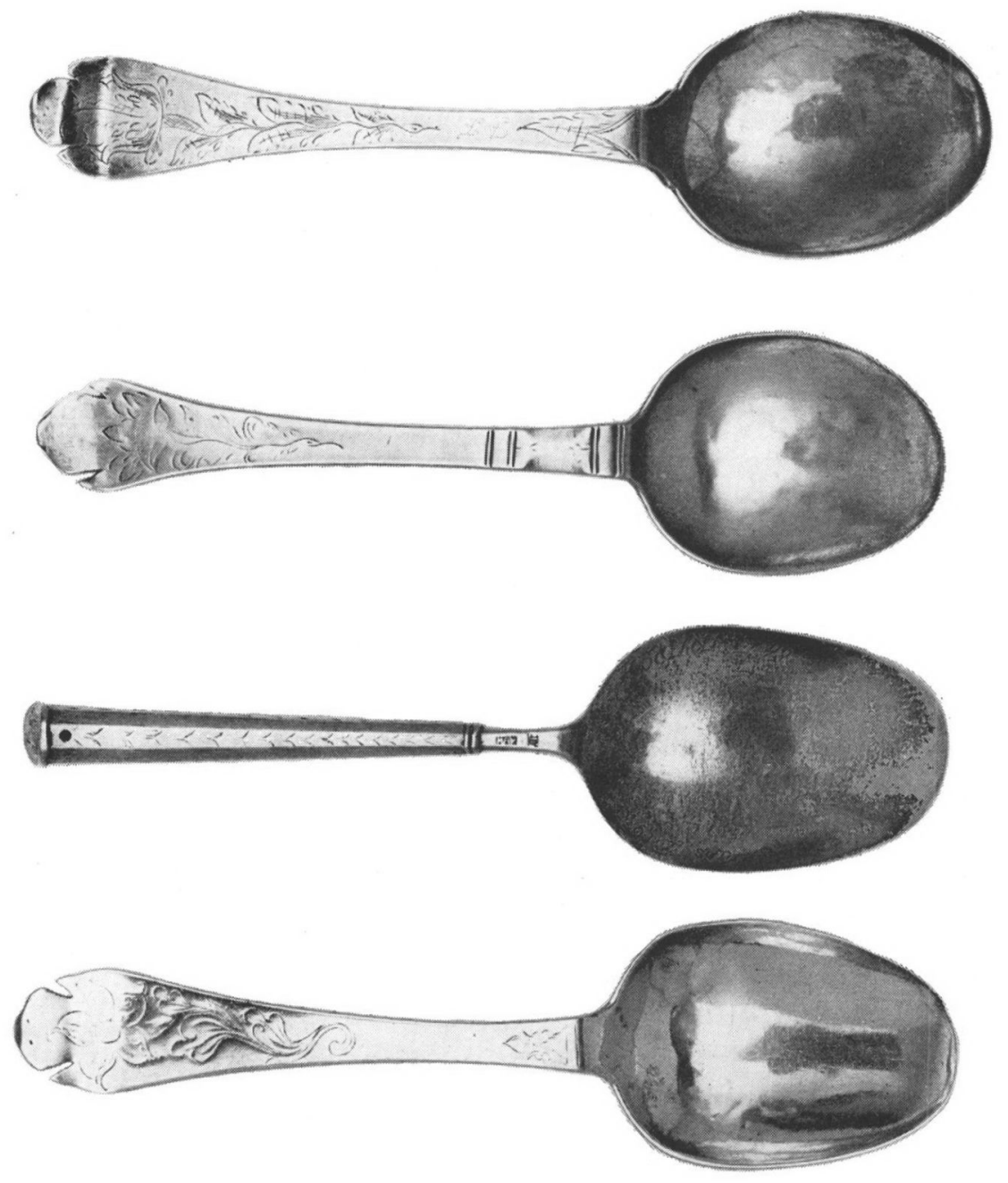
Fig. 18. Spiseske. Barok. 8-kantet hulskaft. Akantusgravure på laffen. Inscr. Hans Lausen in Dalholdt 1753 (jvf. fig. 15). Åbenrå bymærke (Bøje 2. 1374) og mestermarke LT (Bøje 2. 1388) for Ludolph Thiesen. B. 26. 7. 1737 .

Fig. 19. Spiseske. Barok. 8-kantet hulskaft. Som den foregående med markeret rottehale i gravure på laffen. Blomstergravure sst. Sekundar inscr. Nicolay Michelsen 1800. Uden bym. Mestermærke for Rosendahl.

Fig. 20. Spiseske. Barok. Kvallet skaft. Graveret laf og skaft. Inscr. Peter Nissen Ahnholm 1801 (sek.). Abenrå bym. (Bøje 2.1376) og mestermarke for Rudolph Nielsen.

Fig. 21. Spiseske. Barok. Fliget skaft med vanlig gravure. Inscr. Jes Jessen in Barsmark 1749. Åbenrå bymarke (Bøje 2.1373) og mestermærke for Rudolph Nielsen. 

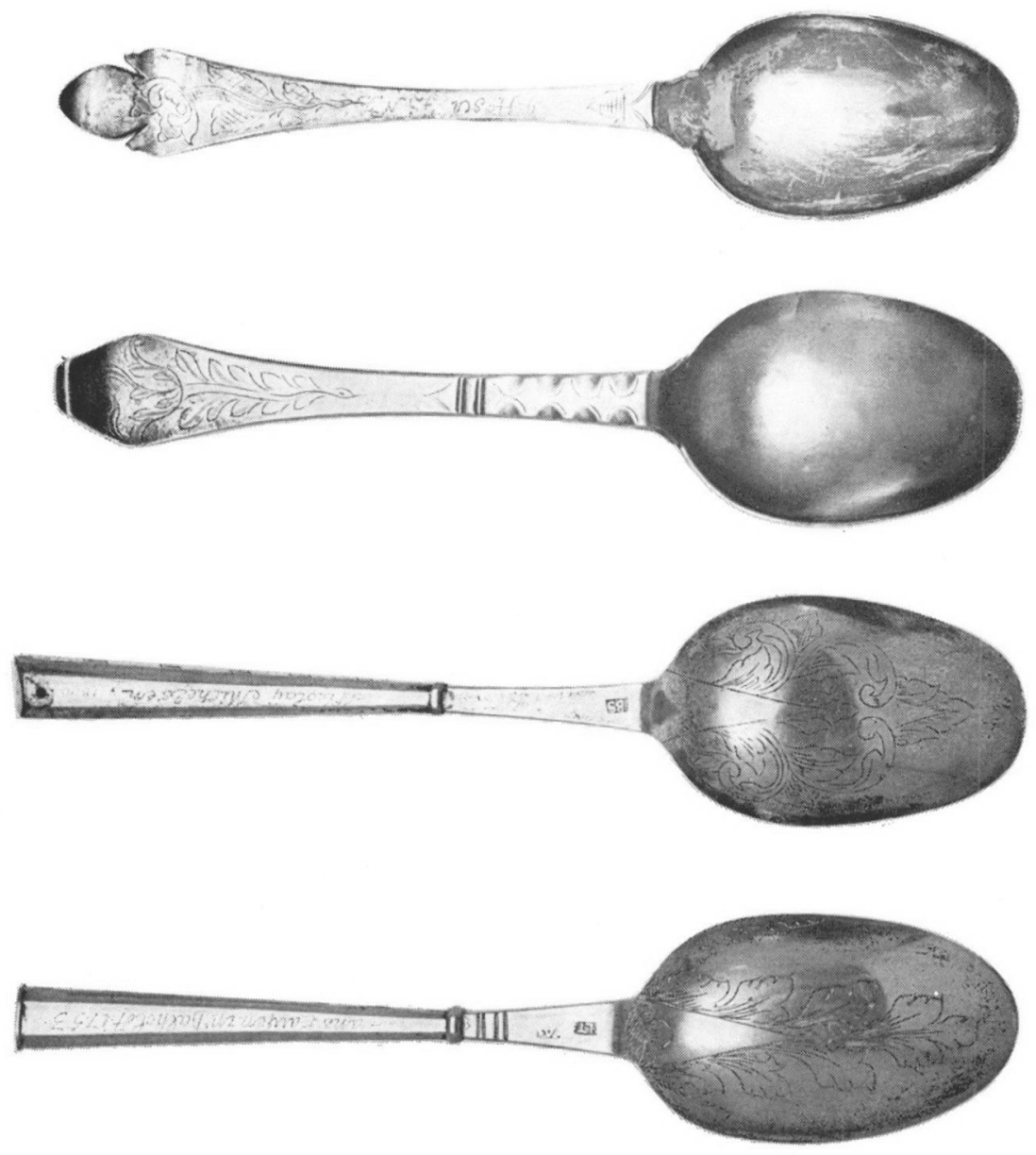
Fig. 22. Spiseske. Louis XVI. Inser. Johann Callesen aus Cassö 1818. Åbenrå bym. (variant til Bøjes) og mestermarke for Fr. Chr. Hansen.

Fig. 23. Spiseske. Louis XVI. Perlestav og ranke. Inscr. N K 1815. Stempler som ovenfor.

Fig. 24. Spiseske. Louis XVI. Støbt urne af Tonder-typen og ranke. Stempler som ovenfor.

Fig. 25. Spiseske. Louis XVI. - Empire. Inscr. Laue Hansen Schmidt 1803. Åbenrå bymærke (Bøje 2.1380) og mestermarke IHS (Bøje 2.1404) for Johan Heinrich Schou (1767-1836), B. 10. 4. 1801. 

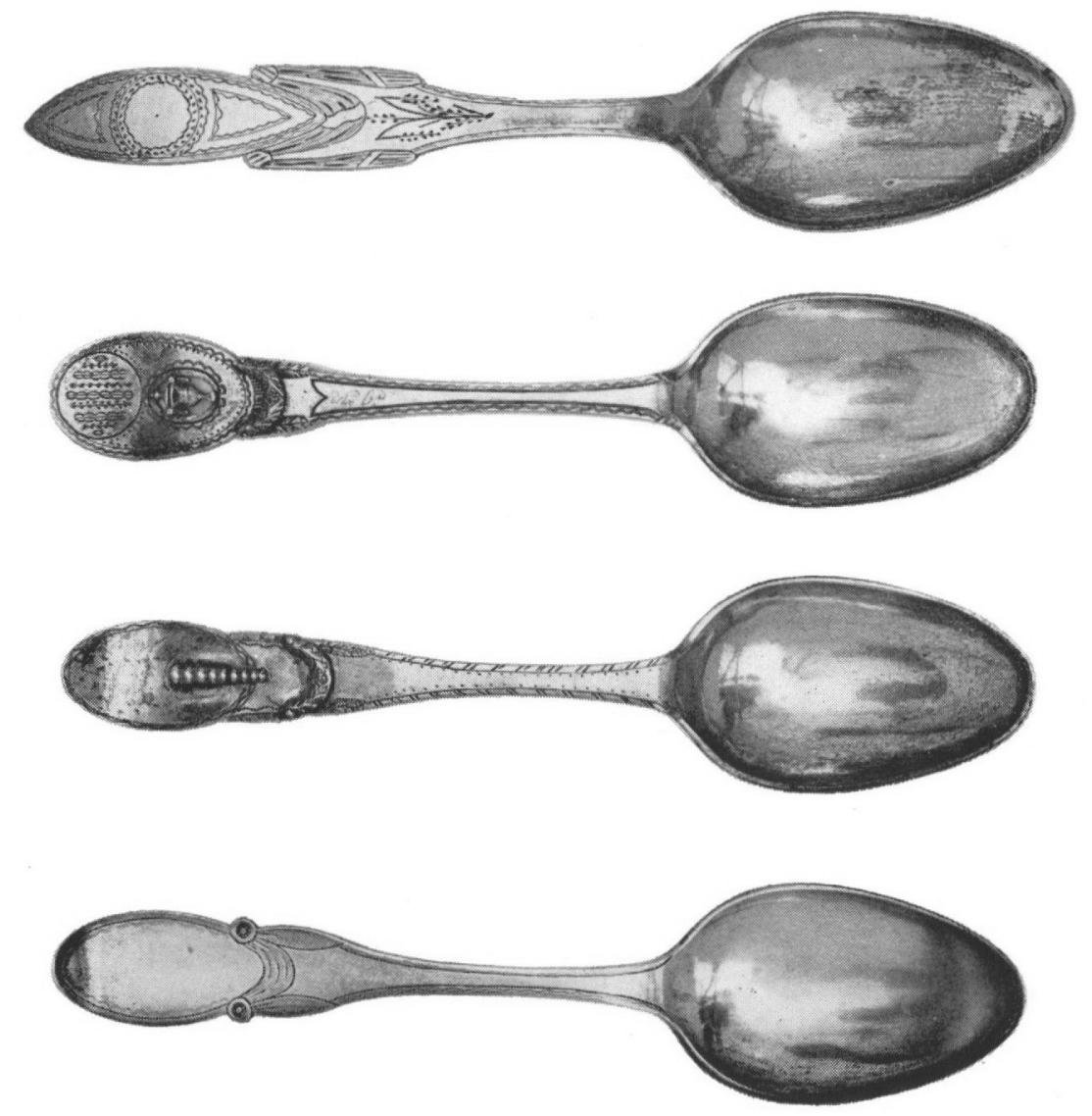
Fig. 26. Skospande. Louis XVI. 4,6 $\times 7,5 \mathrm{~cm}$. Jernspande. Uden bymarke. Mestermarke HO (Bøje 2. 1393) for Hans Offersen (1731--1801), B. 17. 9. 1756.

Fig. 27. Knæspande. Louis XVI. $4,6 \times 7,5 \mathrm{~cm}$. Jernspande. Svarende til fig. 26. Uden bym. Mestermarke TI (Beje 2. 1401) for Thomas Jensen sen.

Fig. 28. Skospænde, Louis XVI. 5,0 $\times \mathbf{9 , 5} \mathrm{cm}$. Jernspende. Inscr. PHS 1795. Urlen bymærke. Mestermærke for Rosendahl. (Bøje 2. 1391, 2 g.). 

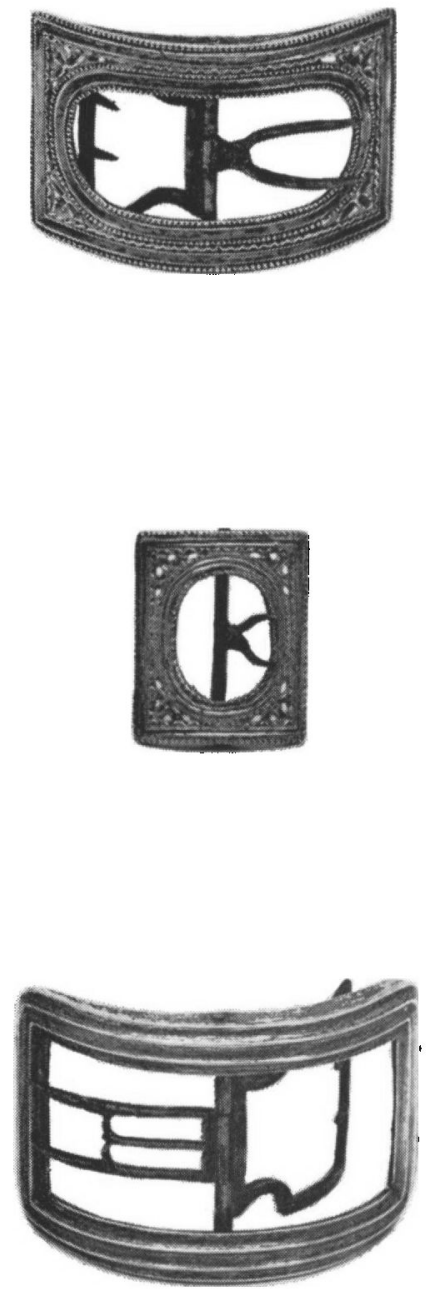
Fig. 29. Glodetang. Barok. Griberne formede som muslinger. Uden bymærke. Mestermarket LT (Bøje 2. 1388) for Ludolph Thiesen.

Fig. 30. Glodetang. Rokoko. Meget smukt stobt arbejue. Åbenrå bymarke (Bøje 2. 1377) og mestermærke FCH (Bøje 2. 1394) for Fr. Chr. Hansen.

Fig. 31. Sukkertang. Louis XVI. Sek. inscr. FF 1837. Åbenrå bymærke (variant til Bøjes) og mestermarke som ovenfor. 


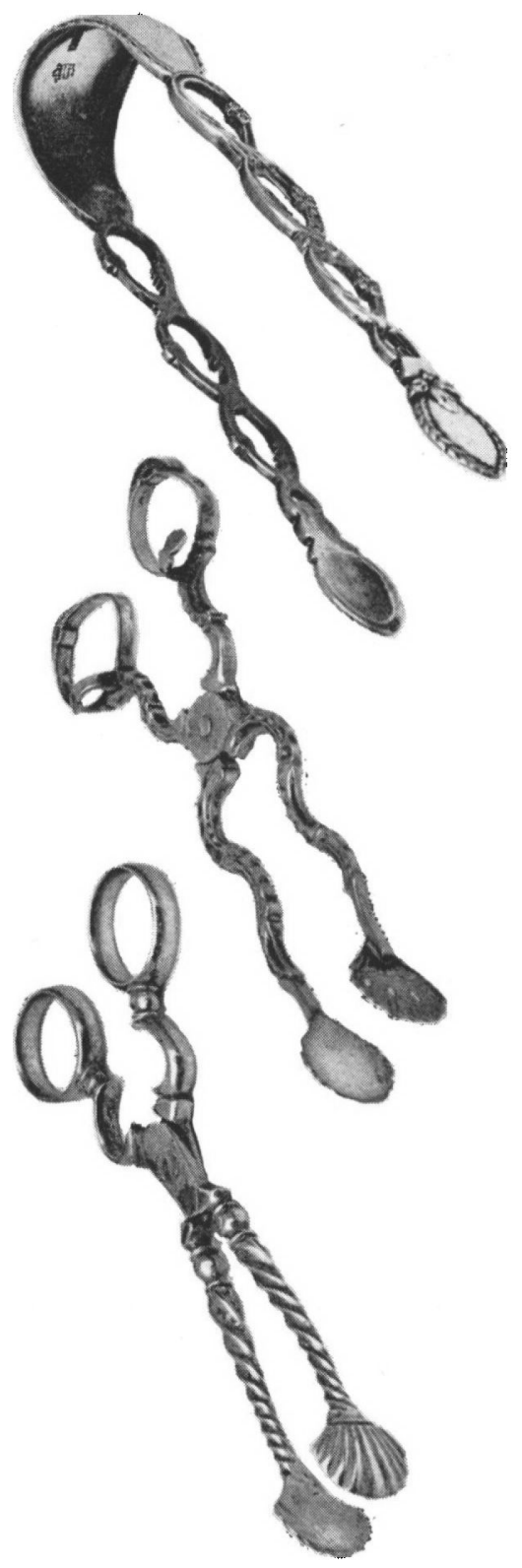


Fig. 32. Hovedvandsæa. I. Iouis XVI. 7,8 cm l.. Opr. helforgyldt. Sekundær inscription: J Jespersen K C J 1857. Uden bymarke. Mestermarke HB. Ej Bøje, men formentlig udfort af Hinrich Breundle.

Fig. 33. Hovedvandseg. Empire. $9,5 \mathrm{~cm}$ h. Opr. helforgyldt. 7 hvirle glasflusser. Inser. IHS 1826. Uden bymarke. Mestermarke TI (Bøje 2. 1401) for Thomas Jensen sen.

Fig. 34. Hovedvandsa'g. Louis XVI. $8 \mathrm{~cm}$ h. Delvis forgyldt. 3 hvide glasflusser. Inscr. N C D. Åbenrå bymarke (Bøje 2. 1381) og mestermærke IHS (Bøje 2. 1404) for Johon Heinrich Schou.

Fig. 35. Hovedvandsag. Empire. $9 \mathrm{~cm} \mathrm{h.} \mathrm{Delvis} \mathrm{forgyldt} \mathrm{og} \mathrm{med} 11$ hvide glasflusser. Inscr. N J 1814. Åbenrå bymarke (Bøje 2. 1380) og samme mestermarke som ovenfor. 

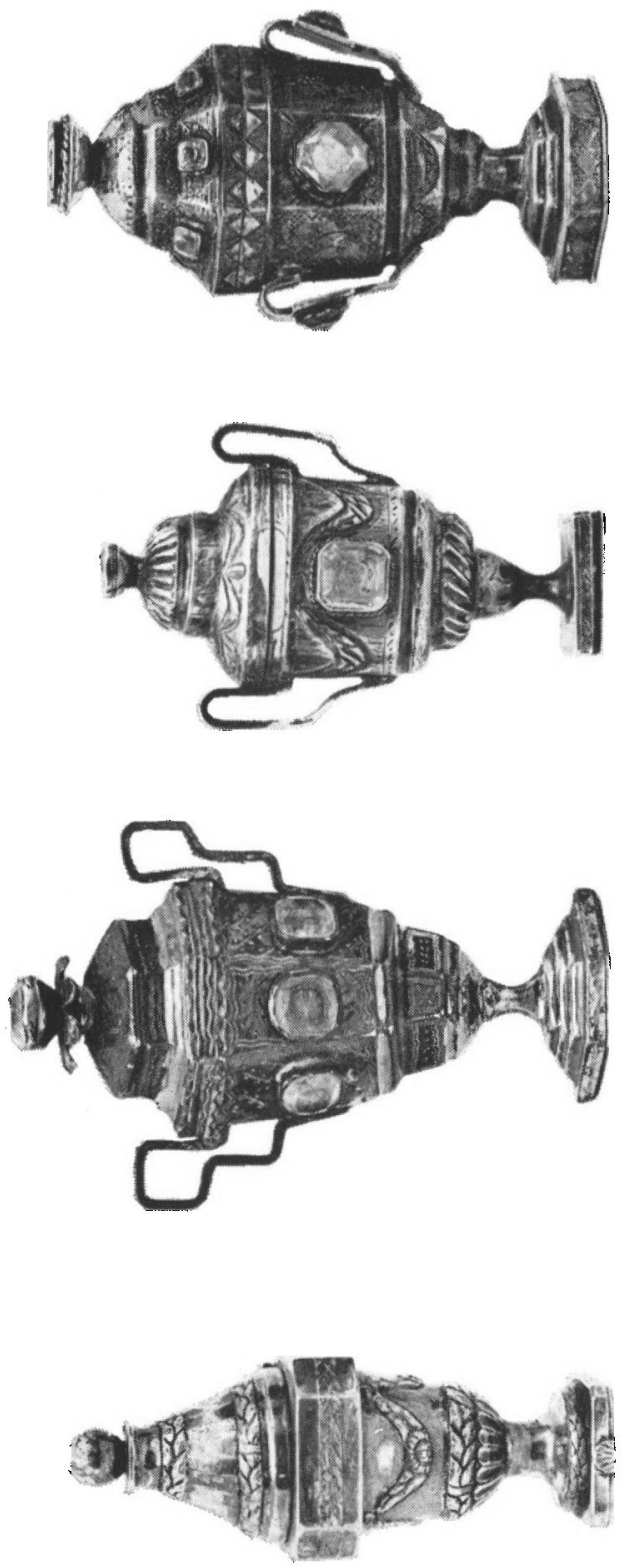
Fig. 36. Hovedvandsæa. Empire. $8,7 \mathrm{~cm}$ h. Delvis forgyldt .11 rode og 2 blå flusser. Inscr. I. B R 1839. Uden bymærke. Mestermærke HB (Bøje 2. 1409) for Andreas Heinrich Golllieb Breundle (1810-66), B. 10.5. 1833.

Fig. 37. Hovedvandsa' og grønne flusser. Åbenrå bymarke (Bøje 2. 1380). Mestermarke CM (Bøje 2. 1427) for Christopher Waidlov Moller (1815 99), B. 24. 5. 1854.

Fig. 38. Hovedvandsag. Senempire. $8,9 \mathrm{~cm} \mathrm{~h}$. Vestslesvigsk aggebagerform. Opr, helforgyldt. Inscr. S. Berg 1852. Åbenrå bymarke (Bøje 2. 1380) og mestermarke TI (Bøje 2. 1424) for Thomas Jensen jun. (1797 1853), B. 10. 3. 1851 . 

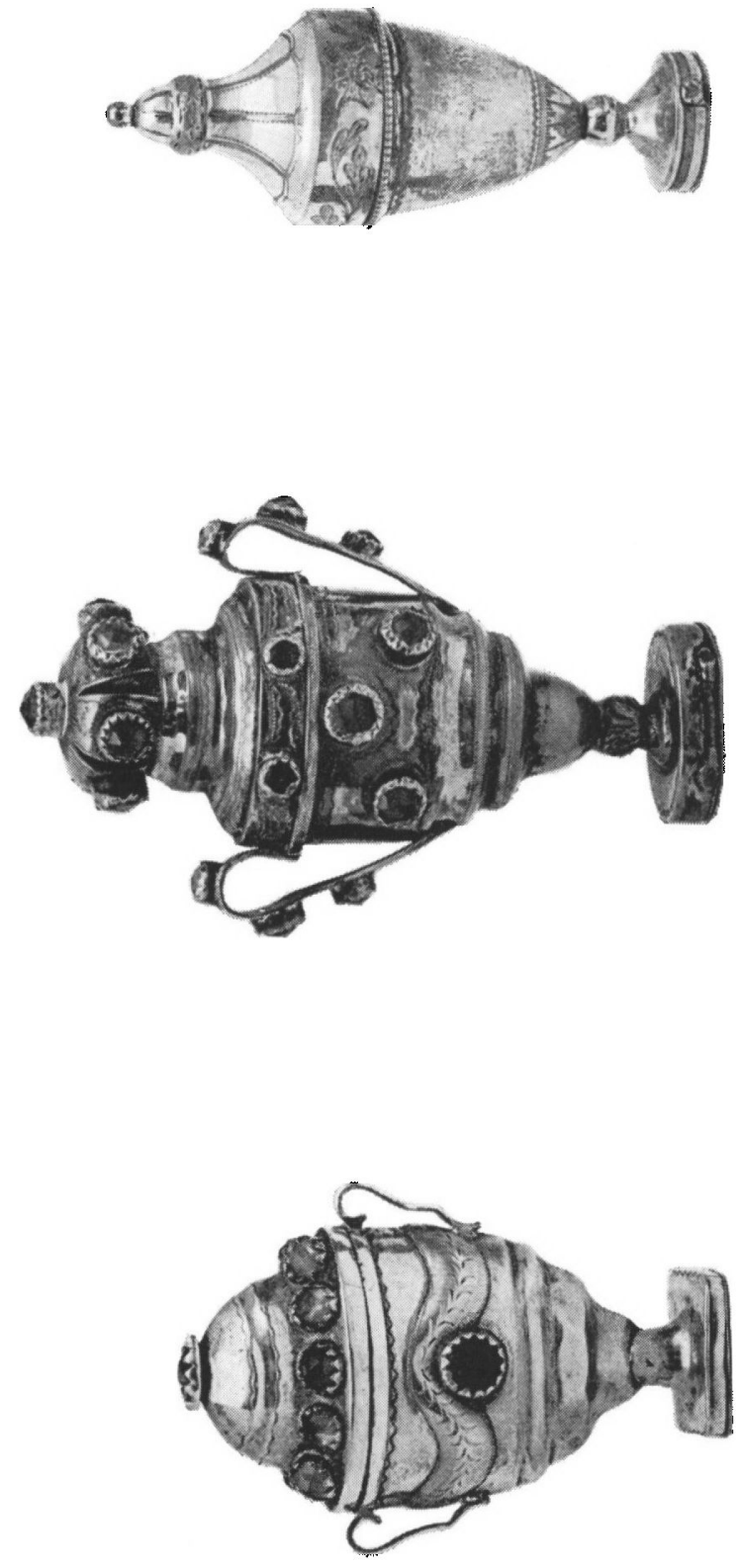
Fig. 39. Hovedvandsu'g. Senempire. $15 \mathrm{~cm} \mathrm{~h}$. Delvis forgylalt. 66 rode, blå, grønne flusser. Inscr. Jürgen Wollsen Warnitz 1844. Åbenrå bym. (Bøje 2. 1380) og mestermarke T Jensen (Boje 2.1426) for Thomas Jensen jun.

32 


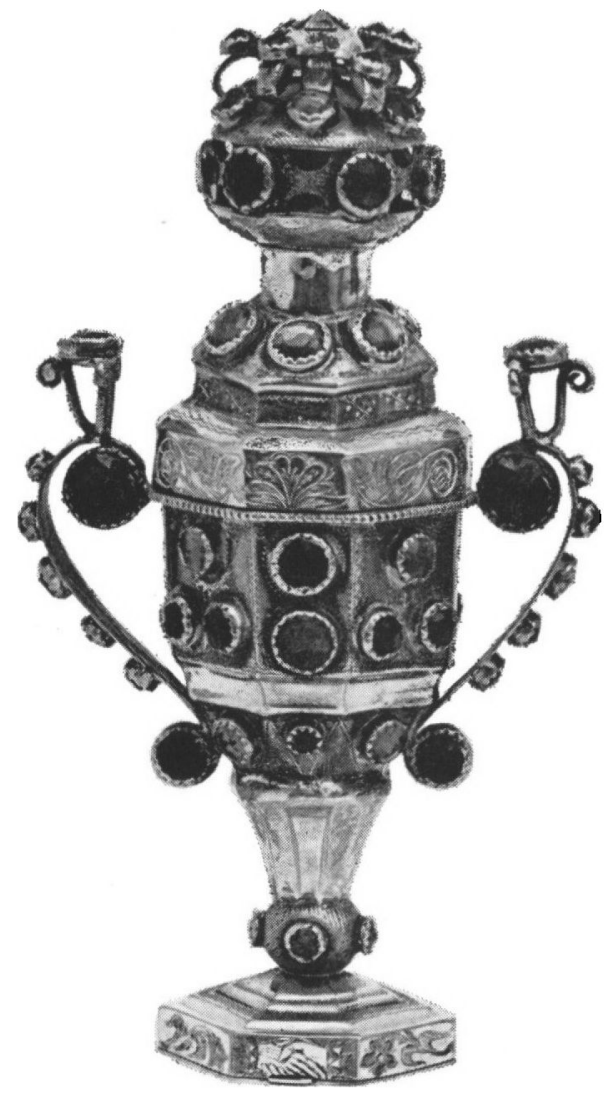


Fig. 40. Hovedvandsæy. Senempire. $14 \mathrm{~cm}$ h. Delvis forgyldt. 102 roble, blå, grønne flusser. Inscr. N. P. Rossen 11' Juni 1845. Åbenrå bym. (Bøje 2. 1379) o gmestermarke Petersen (Bøje 2. 1414) for Peter Johannsen Petersen (1805-73), B. 10. 5. 1833. 


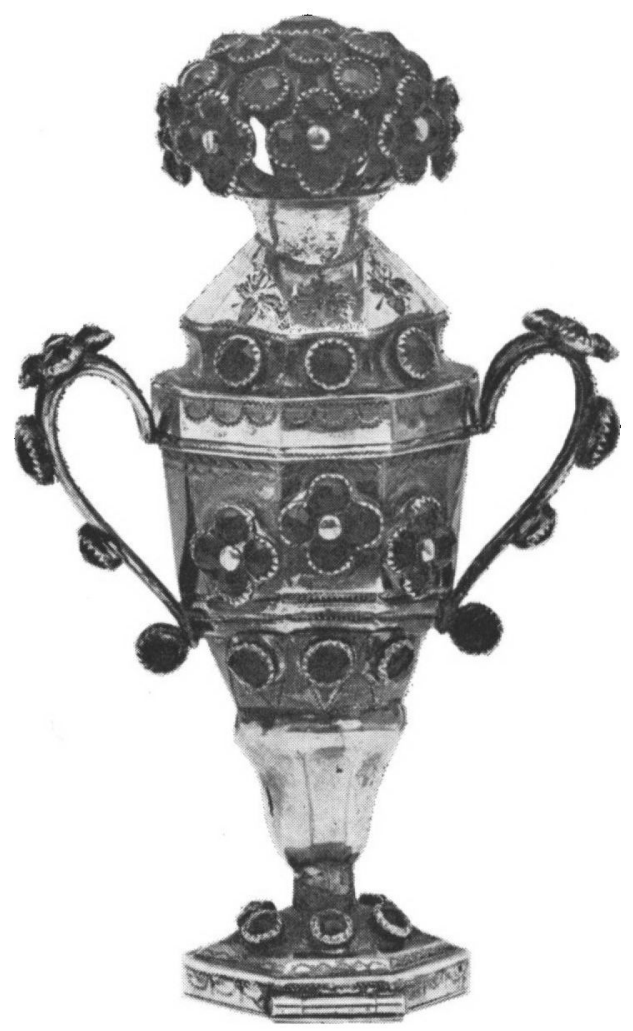


Fig. 41. Salmeboy med beslag. Rammer, hjørner og spander. Regence. Inser. I E S. Uden bymarke. Mestermarke BS (Bøje 2. 1391). Indeholder Ny Testamente 1766 og Ny Psalmebog 1769. Rosendahl.

Fig. 42. Salmebog med sparnde. Kokoko. Inser. J J Blokrug 1815 (sek.). Åbenrå bymærke (Bøje 2. 1380) og mestermærke IHS (Bøje 2. 1404) for Johan Heinrich Schou. Indeholder Varnassalmebogen, Flensb. 1744.

Fig. 43. Salmebog med spæxnde. Rokoko. Fugle i båndslyng. Inscr. J H E 1798. Samme stempler som foregående. Indeholder Ny Psalmebog 1764. 

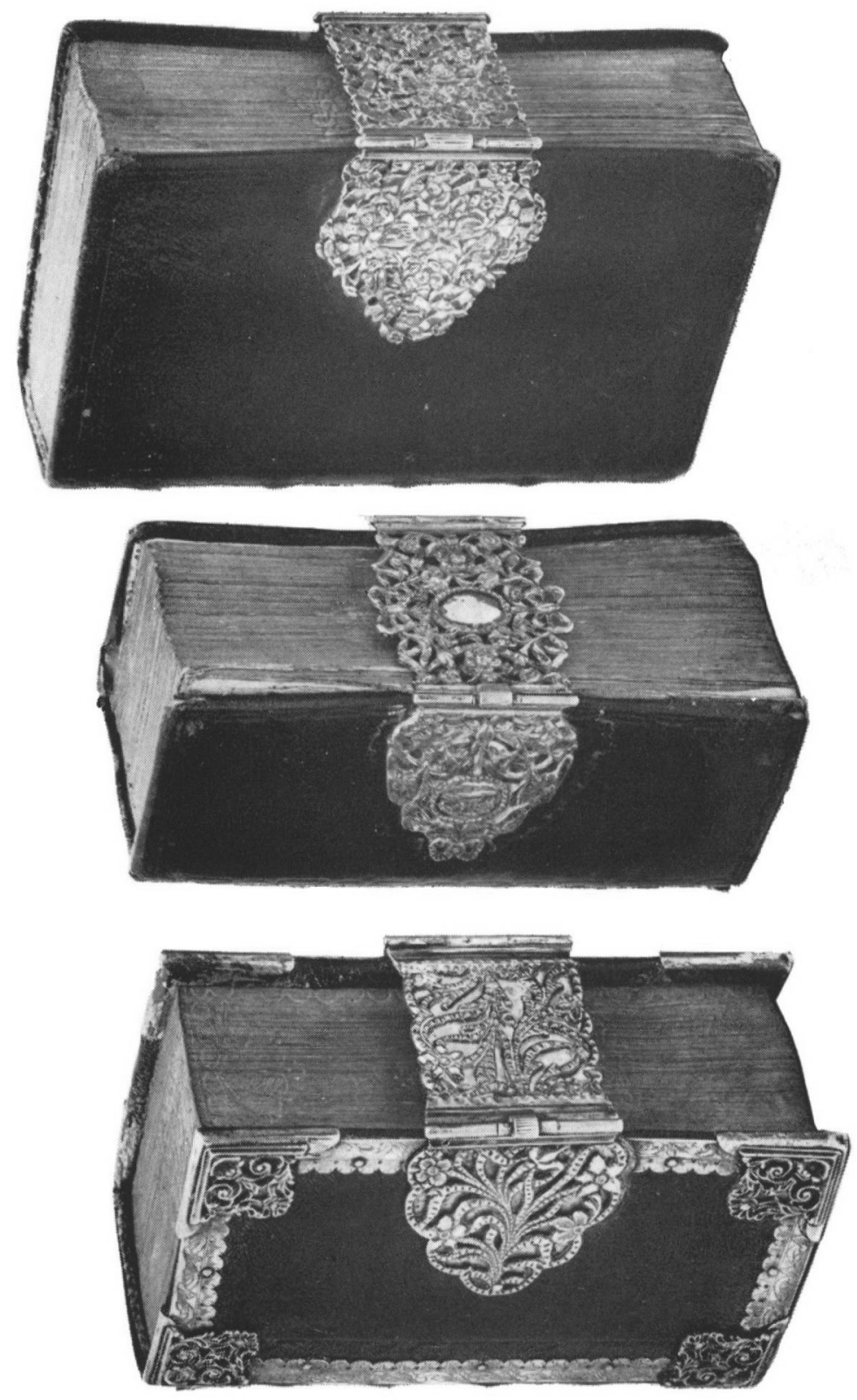
Fig. 44. Salmebog med beslag: Rammer, hjørner og spænde. Rokoko. Inscr. APS 1803. Samme stempler som fig. 42 og 43. Indeholder Varnæssalmebogen, Tønder 1765.

Fig. 45. Salmebog med spande. Rokoko. Samme type som foregående. Inscr.: Friedrika Wold 1820. Nis Richelsen in Wernitz. Åbenrå bymærke (Bøje 2. 1382) og mestermarke DCB (Buje 2.1406) for Diedrich Chrislopher Breundle (1777 1822), B. 27. 2. 1807. Indeholder Varnassalmebosen, Tonder 1755.

Fig. 46. Salmebog med spände. Empire. Medl 3 røde glasflusser. Åbenrå bym. (variant til Bøjes) og mestermærke Petersen (Bøje 1414) for Peter Johannsen Petersen. 

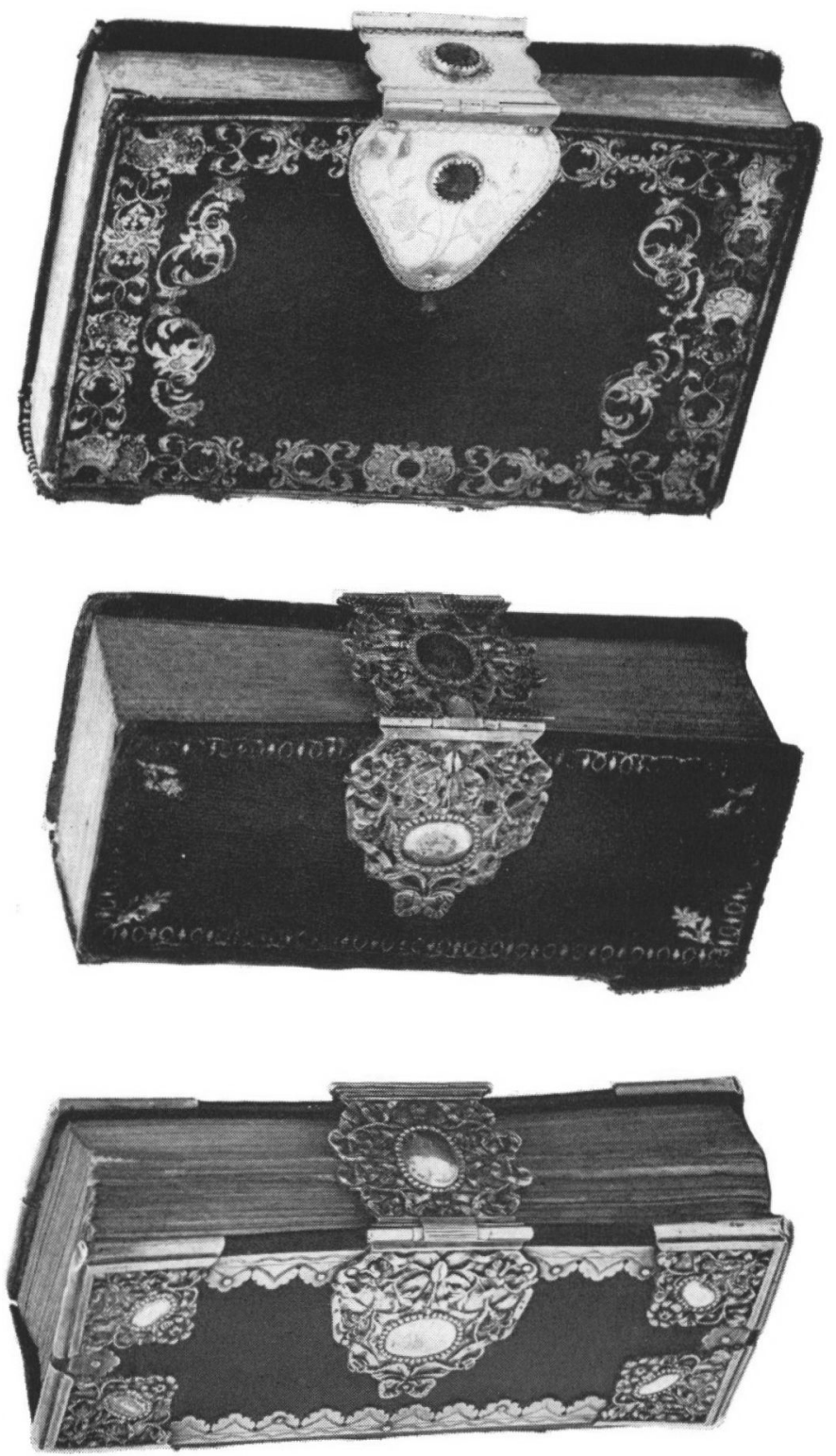
